\title{
Validity Of Fisher Effect Theory: Evidence from The Conventional and Islamic Money Market in Malaysia
}

\section{Nurazilah ZAINAL ${ }^{1}$, Mohammed Hariri BAKRI ${ }^{\star 2}$, Law Siong HOOK ${ }^{3}$, Syahrir ZAINI ${ }^{4}$, Mohd Faizal bin Ab RAZAK ${ }^{5}$}

${ }^{1}$ PhD. Universiti Teknologi MARA, E-mail: nuraz3169@uitm.edu.my

${ }^{2}$ PhD. Universiti Teknikal Malaysia Melaka, E-mail: hariri@utem.edu.my

${ }^{3}$ PhD. Universiti Putra Malaysia, E-mail: lawsh@upm.edu.my

${ }^{4} \mathrm{PhD}$. International Islamic University Malaysia, E-mail: syahrirz@iium.edu.my

${ }^{5}$ PhD. Universiti Malaysia Pahang, E-mail: faizalrazak@ump.edu.my

${ }^{*}$ Corresponding Author

\begin{abstract}
This study attempts to examine existence of Fisher Effect theory in Malaysia's conventional and Islamic money markets. Time series data has been included for the years 2011 to 2018 and consists of two stages of data analysis. First stage analysis examines the existence of a Fisher Effect relationship by applying the Autoregressive Distributed Lag (ARDL) approach as an estimation method. Second stage analysis determines the strength of the Fisher Effect relationship by imposed restriction $\beta=1$ using standard asymptotic Chi-square in Wald test. The findings found that the Fisher Effect theory valid in Malaysia's Islamic money market but there is no evidence for the conventional market. This outcome suggests that the Islamic money market can accurately predict inflation in the future. However, it appears in a weak form of relationship. Overall, outcomes of this study provide benefits for policy-makers since the existence of the Fisher relationship reflects an effective monetary policy for economic growth and sustainable development.
\end{abstract}

Key words: Islamic Money Market, Fisher effect, Inflation rates, Monetary Policy, ARDL cointegration test

\section{Introduction}

For the past three decades, the Malaysian economy has increased its Gross Domestic Product (GDP) by about 7 percent and this has made the country the fast-growing of the Southeast Asian economies. However, unfavorable global economic conditions have put pressure on the Malaysian economic and financial system. An unanticipated collapse heralded by the subprime mortgage crisis in the United States in 2007 sent ripples throughout the Asian economies that caused huge financial turmoil and panic. Malaysia's economy was not exempted from the ensuing global financial crisis (GFC). Zainal et al. (2019) noted that Malaysia went into economic recession in 2008 and the inflation rate reached as much as 8.5 percent. Figure 1 depicts the volatility of the inflation rate in Malaysia.



Figure 1: Inflation in Malaysia 
Based on the figure above, the inflation rate in Malaysia remained highly volatile between 1998 and 2008 but especially during the GFC. The inflation rate rose from 2.7 percent in 1997 to 5.3 percent in 1998 as a result of the Asian financial crisis (Seng et al., 2020). At that time, the Malaysian economy suffered a sharp decline in GDP that was equal to -7.4 percent and unemployment reached the highest level in 1997. It should be noted that inflation leads to high interest rates and this greatly restricts economic growth through low productivity and investment. Exploring the relationship between inflation and interest rates has been a long-standing concern among policymakers and economists. Fisher Effect theory forms the basis of understanding the correlation between inflation and interest rates. Irving Fisher (1930), who devised the Fisher Effect theory explains that nominal interest rate is made up of two components; real rate of return and expected inflation rate. The theory also suggests the nominal interest rates adjust one for one with respect to the changes in the expected inflation rate while the real rate of return remains constant. This forms the foundation for the interest rates theory and his hypothesis is one of the most influential theory in economics since it has elicited important policy implications.

An examination of the validity of the Fisher Effect relationship has widely been conducted in emerging and developed countries. For the latter, Darby (1975) found the Fisher Effect theory is rejected when the interest on income tax and interest rates increases more than the increase in inflation rate. In the same vein, Weidmann (1997) re-investigated the existence of the Fisher Effect in Germany and the findings disclose the non-existence of a Fisher relationship since interest rate does not respond to any variation in the inflation rate. This is contrast to Panpoulou (2005) who discovered evidence of a full Fisher Effect in 14 OECD countries where the interest rate changed one-for-one with the inflation rate. Lee (2007) examined the Fisher Effect theory in Singapore and found a positive correlation between interest rate and inflation rate, however, it was unable to support the full Fisher Effect. As well, Awomuse and Alimi (2012) explained interest rates and inflation rate as moving together in the long-run but their findings do not support a full Fisher relationship in Nigeria. Mahmood Ali et al. (2015) have found evidence of the Fisher Effect in both the short- and long-term cointegration of the exchange rate, interest rate and inflation rate in Pakistan. Moreover, Anari and Kolari (2016) support the Fisher relationship in the US by including ex ante and ex post coefficients in the data estimations.
High volatility in the interest rate and inflation rate has attracted the interest of governments and policymakers. Generally, the main role of government as the appointed monetary authority is to formulate effective monetary policy through money supply adjustment in the financial market (Mohd Noor et al., 2020). Auclert (2019) suggests that monetary policy is effective when interest rates move accordingly with expected inflation rate which indicates the existence of a Fisher Effect relationship. Practically, the government conducts monetary policy by controlling the amount of money supply in the economy since the money market is the largest one in the financial system and free interest rate risk as backed by the government. The inflation rate could be adjusted by the government by stabilize the amount of funds in the market, for instance excessive funds will lead to low interest rates and high inflation. So the government will sell government securities to mop up any excess liquidity and this leads to rising interest rates and falling inflation. Therefore, discovering the interest-inflation relationship in the Fisher Effect theory is deemed to be essential by economists.

The money market is the largest one in the financial system and it has been accepted by many studies as a basis rates for measuring interest rates. Zainal et al. (2014) write that the money market in Malaysia was established in 1980 and this widened when the Islamic Interbank Money Market (IIMM) entered the scene in January 1994. The main purpose of IIMM is to help Islamic banks to adjust their investment portfolios through short-term funding facilities. The structure of the Malaysian money market can take the form of either direct borrowing and lending among commercial banks. The government, corporations and commercial banks appear to be the main participants in the money market, which plays a significant role in assisting them to manage liquidity. It does this by synchronizing their cash inflows and outflows and money supply control. With this in mind, Malaysia is a country operating a dual banking system where the conventional market operates in parallel with the Islamic market (Vianneca W. Jubilee et al., 2020). After three decades since the establishment of the Islamic money market in Malaysia, it is growing rapidly throughout the country. This situation is fully reflected by the huge amount of funds which have been channeled to the Islamic money market, which ranges monthly from RM30 billion to RM40 billion. Figure 2 depicts the volume transaction for conventional and Islamic money markets in Malaysia.

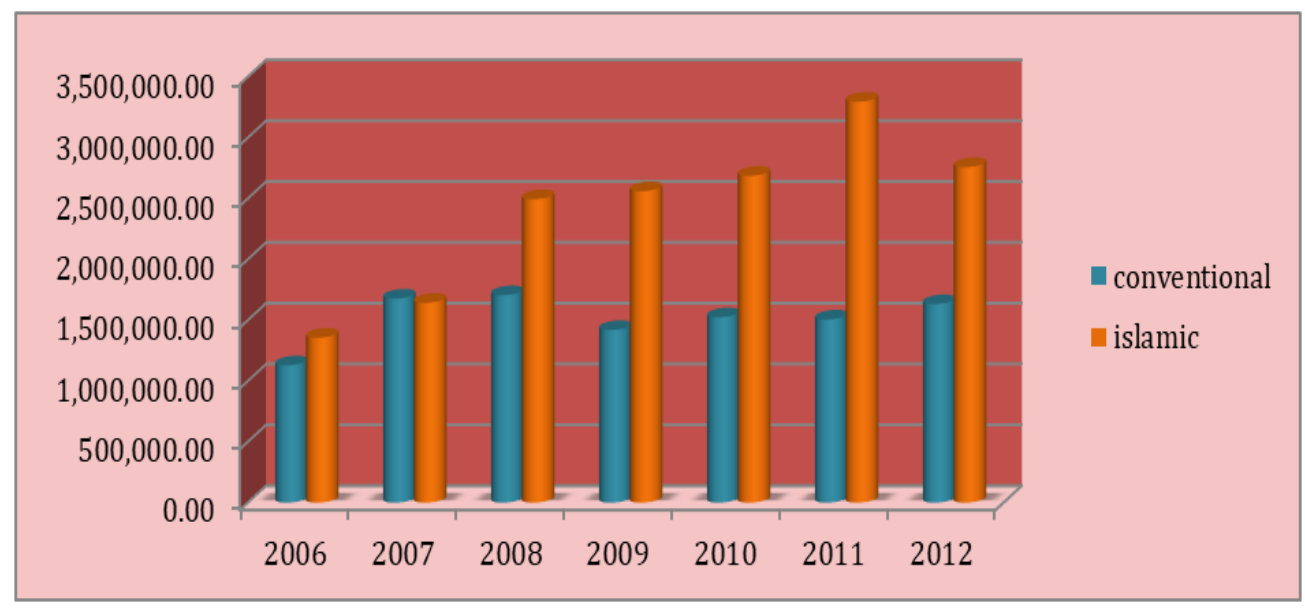

Figure 2: Volumes of the Conventional and Islamic Money Markets

Based on Figure 2, it can be seen both conventional and Islamic markets were highly competitive during the early years.
Later, Islamic market transactions increased tremendously until these took the lion's share of the money market and left 
the conventional market stagnant. Increasing demand by global and local investors especially in Islamic products and supportive policy environment has contributed to the predominance of the Islamic money market. In Malaysia, the justification of the Fisher Effect towards volatility in inflation has been argued by economists over a long period of time (Zainal et al., 2014). In their analysis, Geetha et al. (2011) determine the existence of a Fisher relationship in the stock markets of China, Malaysia and the US. The findings support the existence of a Fisher relationship when a long-run relationship exists in stock returns and inflation rate in all countries. Moreover, Asari et al. (2011) set out to establish the validity of a Fisher relationship in the Malaysian exchange market but did not detect a Fisher relationship since a negative relationship appeared between the exchange and inflation rates. Recently, the presence of a Fisher relationship has been examined in the Malaysian capital market. Fah and Annuar (2012) disclose the validity of such a relationship in the capital market when they found a long-run relationship between the return for Malaysian Government Security and Gross Domestic Product (GDP) deflator.

Referring to the Islamic countries, many studies have proven the validity of Fisher Effect theory (Mahmood Ali et al., 2015; Alsmadi and Almsafir, 2013; Fatima and Sahibzada, 2012; Mahdi and Masood, 2011). They confirm the ability of interest rates in Islamic markets as a predictor of future inflation. Specifically, it highlighted the potential of the Malaysian Islamic money market to predict future inflation. Only a limited number of studies have examined the existence of a Fisher Effect between interest rate and inflation rate for the Malaysian money market. In general, variations between conventional and Islamic market are obvious in terms of principles being applied. In the Islamic market, Shariah principles are the basis of running an Islamic business and they prohibit certain activities such as gambling (maisir), uncertainty (gharar), and charging interest (riba). Also the funds are strictly guarded so that they do not deal in non-halal activities. In contrast the conventional money market is one where there are no restrictions on the flow of funds in investment activities. Linked to this issue, the interest rate in conventional and Islamic market could behave differently with the variation of the expected inflation rate. The outcomes from this study may provide solutions to the research question below:

"Can the conventional or Islamic money market in Malaysia accurately predict inflation in the future?"

This paper attempts to examine the existence of a Fisher Effect relationship in the conventional and Islamic money markets in Malaysia as the first objective. Second, it determines the one-to-one relationship between interest and inflation rates as implied by the theory of Fisher Effect. Section 2 presents an overview of the theoretical and empirical literature on both the interest rate and inflation rate in the context of Fisher Effect theory. Section 3 explains the estimation model and estimation method undertaken to fulfil the objectives of this analysis. It is followed by section 4 which discusses the results of the empirical analysis on the validity of Fisher Effect relationship in the Malaysian money market. Section 5 delivers the conclusions and a summary of the main themes covered here.

\section{Background Theory and Literature Review}

Irving Fisher (1930) devised a theory to explain the correlation between nominal interest rate and inflation rate and this is known as the Fisher Effect theory. It comprises three elements: 1) nominal interest rate; 2) expected inflation rate; and 3) real interest rate. Fisher also proposed the real interest rate is persistent while the changes in inflation rate reflect the changes in nominal interest rate. Nevertheless, the real interest rate is not persistent forever. Nusair (2009) asserts that the real interest rate is affected by real economic indicators such as capital productivity and investors preferences.

The theoretical equation for the Fisher theory is shown below:

Nominal interest rate

$$
i_{t}=R_{t}+\beta \pi_{t}^{e}+\varepsilon_{t}
$$

(1)

First, nominal interest rate is the value debtors have to bear for a temporary borrowed fund (Obi et al., 2009). Usually when the interest rate reaches its peak, this leads to an unfavorable situation for the debtor since the cost of borrowing is higher, whereas low interest rate provides a more favorable scenario for debtors because it lessens the cost of borrowing. Moreover, based on interest rates are determined from the point of equilibrium supply and demand in the capital market. Second, the real interest rate generally has been explained as a determinant of saving and investment behavior among households and businesses and it wields a significant impact on the growth and development of an economy. The real interest rate varies from interest rate since it is persistent with changes in inflation. Third, inflation rate explains the situation where rises in prices of goods and services in the economy for a particular period have been known to indicate the value of money. When inflation rises the balance of payments, production, trade deficits and aggregate demand will fall. Apart from that, a supportive environment and continuous support from a government for economic activities leads to a low and moderate inflation level which is reflected in reduced unemployment rate, eased balance of payment problem and rising GDP.Following Mishkin (2016) the role of Fisher theory has been supported as a key component in economic literature. First of all, the important role is evident in the real interest rate in economic growth, investments, and savings at the same time - they all affect capital flows and trade through the exchange rate. Secondly, as suggested by Fama (1975) it has been widely accepted in the literature that interest rates are a predictor of future inflation rate. Thirdly, the central bank claims the Fisher relationship is an indicator for effectiveness implementation of monetary policy.

A comprehensive review of the literature on the Fisher Effect is presented in this section. Atkins (1989), Crowder and Hoffman (1996) and Evans and Lewis (1995) were early studies that supported the Fisher Effect by including after-tax interest rates in their data analyses. Atkins (1989) and Evans and Lewis (1995) proved the validity of long-run cointegration in the United States by undertaking various methods of cointegration investigation. In their different research strategy, Crowder and Hoffman (1996) found that after-tax interest rate is fully adjusted to movements in inflation and subsequently provides evidence of Fisher Effect theory.

Recently, Auclert (2019) reveals three elements which are monetary expansion, inflation and real interest rate as confirming the existence of the Fisher Effect in Italy and the US. El-Seoud (2014) investigated the Fisher correlation between GDP, interest rate and inflation in Bahrain. The result discloses the existence of short- and long-term correlations between interest rate and inflation, which confirms the Fisher theory. Elsewhere, Anari and Kolari (2016) examine the Fisher and Wicksell process by including ex post interest and inflation rate in their analysis. The results support both the Fisher and Wicksell in explaining Fisher Effect theory in US financial 
market. Nevertheless, several researchers failed to find evidence for the Fisher Effect in their studies. For example, Dutt and Ghosh (1995) examine the relationship between the period of floating and a fixed exchange rate. Their findings provide no evidence of a Fisher Effect for both regimes. This is consistent with findings reported by Junttila (2001) who failed to detect a Fisher relationship in Finland. Moreover, the evidence of a Fisher Effect in the United Kingdom is not significant (Evans, 1998). Meanwhile Fahmy and Kandil (2003) investigate the validity of a Fisher relationship between return on US Treasury security and return for commercial paper with the inflation rate for the period 1980 to 1997 . The results disclose only the validity of a long-run Fisher Effect but not in the short-run, so consequently there is no evidence to support a Fisher relationship. Malaysia is a developing country with a steadily growing economy. The correlation between interest rate and inflation that has been suggested by Irving Fisher (1930) is still inconclusive. Early research on the validity of the Fisher Effect in Malaysia was done by Md Nassir et al. (1987). This research uses the treasury bill rate to proxy for the interest rate and the finding suggests there is no evidence that the short-term interest rate can predict inflation in the future. Fah and Annuar (2012) investigate the validity of the Fisher Effect in Malaysia's bond market. Quarterly data of Malaysian Government Security (MGS) and GDP deflator present a longrun relationship in the findings. The authors discovered a unidirectional relationship between the MGS spreads and GDP deflator in Granger causality test. The evidence for a Fisher relationship in Malaysia is supported by Zainal et al. (2014) when they found a long-run cointegration between Malaysian Treasury bills, interbank rate and inflation rate. This study reveals the interbank rate holds a strong kind of Fisher relationship so it indicates one-for-one movement between interest rate and inflation. The adjustment between stock return and inflation rate has largely been investigated in Malaysia (Hawati et al, 2010; Geetha et al., 2011). Hawati et al. (2010) provide evidence concerning the Fisher Effect in the Malaysian stock market. The findings reveal the adjustment between inflation and stock returns exists after including industrial production and money supply as a control variable. Likewise, Geetha et al. (2011) studied the relatiosnhip between stock returns and inflation rate in Malaysia, China and the United States. The findings disclose that a long-term relationship exists between stock returns and unexpected and expected inflation in all countries except for short-run relationship, which is only supported in China.Asari et al. (2011) looked at the existence of Fisher Effect in Malaysia's exchange market. They include the movement among interest rate, exchange rate and inflation from 1999 to 2009. The results reveal the interest rate is positively significant with the inflation rate in the long-term, which suggests the existence of Fisher Effect theory. Unfortunately, no evidence of Fisher Effect has been found in the exchange market since it responds negatively to inflation rate. Nowadays, the Islamic market is very big compared to its conventional counterpart. Saudi Arabia, Turkey, Pakistan, Kuwait, Iran, and Egypt own the largest Islamic money markets globally. This scenario brings opportunities to investigate if the Islamic money market can accurately predict inflation in the future, and with reference to the validity of Fisher Effect theory which has been tested in Islamic countries. Overall, the findings are unpredictable for most Islamic countries and this reveals evidence for Fisher Effect theory.The latest evidence on the validity of a Fisher relationship in Islamic countries has been found in Pakistan. Mahmood Ali et al. (2015) employ the Vector Error Correction Model and Johansen cointegration approach to find a correlation between money supply, exchange rate, interest rate and inflation. Their findings conclude that only money supply and exchange rate have a short-run and long-run relationship with inflation in Pakistan. Alsmadi and Almsafir (2013) investigate the relationship between macroeconomic conditions, conventional interest rate and Murabahah (Islamic rate) and inflation rate. Their results report evidence of significant influence wielded by inflation rate on Murabahah but no evidence for the conventional interest rate. They conclude the Islamic market in Jordan achieves equilibrium faster than the conventional one. Al-Sharkas and Al-Zoubi (2013) evaluate the relationship between inflation and stock price in four Arab nations for the period 2000-2009 by employing Johansen Juselius cointegration. The results from this study provide evidence of a Fisher Effect relationship for all countries excluding Kuwait.Furthermore, Fatima and Sahibzada (2012) examine the existence of Fisher Effect theory by employing error correction model and Johansen Juselius cointegration approaches. The study also determines a directional relationship by applying Granger causality test and variance decomposition model to describe the error correction model. The output from this research confirms the existence of a Fisher Effect in Pakistan. Meanwhile in Turkey, Gul and Acikalin (2008) and Gul and Ekinci (2006) undertake Johansen Juselius cointegration to test the validity of the Fisher Effect. The long-term relationship among interest rate and expected inflation rate were reported in the research findings. Ahmad (2010) examines the existence of the Fisher Effect in Asia and the Middle East, specifically for India, Saudi Arabia, Pakistan, Kuwait, Sri Lanka, and Bangladesh. By employing the ARDL cointegration approach, the findings reveal the existence of a weak Fisher Effect relationship in India, Saudi Arabia, Kuwait and Pakistan. However, no evidence of a Fisher relationship has been found for Bangladesh and Sri Lanka. In Iran, the evidence of Fisher Effect was examined by Mahdi and Masood (2011). They employed Vector Error Correction Model and Johansen Juselius cointegration to check if there was any long-run cointegration between the interest rate and inflation rate. The outputs provide evidence of a weak Fisher effect as causing the expected interest rate on facilities but not driven by market forces. To conclude the above review of the relevant literature, a few issues have been identified in this research study. Generally, much evidence has been found to support Fisher Effect theory in Islamic countries. Meanwhile in Malaysia, the banking system is unique as it operates a dual banking system which means Islamic banking operates in parallel with a conventional banking industry. From the literature, we notice there is a paucity of research in Malaysian Money Market on the examining the movement between interest rate and inflation rate as been suggested by Fisher Effect theory. The present study therefore attempts to bridge the gap in the literature by documenting new empirical evidence on the existence of a Fisher Effect relationship in Malaysia's conventional and Islamic money market.

\section{Data Collection}

This study consists of monthly time series data for an 8year period from January 2011 until December 2018. The data for all variables are extracted from Bank Negara Malaysia's annual reports. For dependent variables, the data for conventional money market rate is gauged by Malaysian Treasury Bills (TB) and Interbank Rate (IR) and Islamic Interbank Rate (IMR) and Malaysian Islamic Treasury Bills Rate (ITB), which have been chosen to proxy the interest rate in the Islamic market. Referring to the independent variable Consumer Price Index (CPI) - it has been included to proxy for inflation in this study. Normally the CPI is employed to gauge the period of inflation and deflation. Mahmood Ali (2015) 
suggest that in the short period, an increase in CPI indicates the period of inflation while decline in CPI which is a signal for deflation.

\subsection{First Stage - Autoregressive Distributed Lag (ARDL) Cointegration Approach}

This study employs the ARDL cointegration approach to examine the validity of Fisher Effect in the Malaysian money market in the first stage of analysis. Pesaran et al., (1999) introduced the ARDL bounds cointegration approach and this was continued by Pesaran et al. (2001). The ARDL analysis is a recent cointegration method named after the Johansen Juselius (Johansen and Juselius, 1990) and Engle Granger (Engle and Granger, 1987) methods. The ARDL cointegration consists of two steps: 1) ARDL bounds test; and 2) ARDL level relationships. The main feature of the ARDL cointegration is that it enables a separate order of integration and is not limited to the same order of integration between the variables. This situation is most appropriate for those variables that have a fractional order of integration (Pesaran et al., 1999). Moreover, this method can identify the long-run relationship for two or more variables in a small sample size when compared to the Engle and Granger (1987) and Johansen and Juselius (1990) approaches. Besides that, Pesaran et al., (1999) suggest the ARDL cointegration delivers super-consistent long-run coefficients estimators. Many studies have proven the existence of Fisher Effect by employing ARDL cointegration as the preferred research method. It is important to check the stationarity for all variables to determine the integration order prior to ARDL bounds test. There is a large debate among the researchers who claim that $A R D L$ cointegration is not required for preliminary testing of stationarity in order to identify the variables' integration order. However, based on Alimi and Ofonyelu (2013) this preliminary check is important for modelling under the ARDL model since it ensures none of the variables are integrated in the order I(2). Ouattara (2004) explains any variable with integrated order of $\mathrm{I}(2)$, the computed F-statistics are invalid since the critical values for the bounds test as proposed by Pesaran et al. (2001) covers the variables ranging from $\mathrm{I}(0)$ or $\mathrm{I}(1)$. Therefore, preliminary unit root tests before employing the ARDL approach are needed to confirm none of the variables were integrated with the order of two or more. The next stage is to continue with ARDL bounds test as suggested by Pesaran et al. (2001), in order to examine the existence of a long-run relationship between interest rate and inflation rate. Depicted below is the $\operatorname{ARDL}(p, q)$ model used to examine the long-term relationship between the variables:

$$
i_{t}=c+{ }_{1} i_{t 1}+{ }_{2} x_{t 1}+\sum_{j=1}^{p} i_{i}+\sum_{i=1}^{q 1} x_{t i}+x_{t}+{ }_{t}
$$

Where, $\Delta$ presents the first difference operator, it $=$ interest rate (IRt,TBt IMRt,ITBt); $x t=$ inflation rate $(\mathrm{IFt})$ and $\left(\varepsilon_{\mathrm{t}}\right)$ represents white noise error term. In addition, $q$ and $p$ are the autoregressive lag orders of the dependent and independent variables, respectively.

The long-run cointegration in equation (2) can be estimated through F-statistics and ordinary least squares. A Schwarz Bayesian Criterion (SBC) has been chosen for the selection of optimal lag length. Following Pesaran et al. (2001), the critical values of this test are valid for the variables stationary at $\mathrm{I}(0)$ and I(1). The critical value contains two sets of lower and upper bounds. An alternative hypothesis is confirmed when the calculated F-statistics fall above the upper bound, which presents the existence of a long-run relationship between the interest rate and inflation rate. Otherwise, if the calculated Fstatistic falls below the lower bound, the null hypothesis is supported and this indicates no long-run cointegration between the interest rate and inflation rate. Additionally, if the calculated $\mathrm{F}$-statistics fall between these bounds then the result is inconclusive.

Furthermore, El-Seoud (2014) mention another option to identify a long-run relationship in the estimation model is with the presence of significance lagged in Error Correction Model (ECMt-1). They suggest a significant and negative value of ECMt-1 reveals the existence of long-term cointegration which confirms the Fisher Effect. The coefficient on ECMt-1 also indicates the speed between interest rates and inflation will attain their equilibrium in the long run.

\subsection{Second Stage - The Coefficients of Fisher Relationship}

In the first stage of analysis, the long-run cointegration between interest rate and inflation rate that validates the Fisher relationship has been identified. Meanwhile in the second stage of analysis the one-to-one relationship as suggested in the theory of Fisher Effect is specified. Practically, the long-run relationship between the interest rate and inflation rate deliver evidence for the Fisher Effect theory. Although the theory does not completely rely on the presence of a long-run relationship, it is essential for the interest rate to move one-to-one with inflation (Anari and Kolari, 2016). There are two types of Fisher relationship, namely weak and strong relationship. The types of Fisher relationship are measured from the value of $\beta$ given in equation (1). Anari and Kolari (2016) also propose spotting a one-to-one relationship between interest rate and inflation; the restriction $\beta=1$ must be imposed in the cointegration model. This hypothesis can be examined by applying standard asymptotic Chi-square in Wald tests and $\beta=1$ denotes a strong Fisher Effect relationship.

\section{Results And Analysis}

Prior to the ARDL bounds test, it is essential to determine the order of integration for all variables. For this purpose, we undertake Augmented Dickey-Fuller (ADF) and Phillips-Perron (PP) unit root tests to check the integration order of the variables (Dickey and Fuller, 1979, 1981; Phillips and Perron, 1988).

The ADF test is only valid if $\mathcal{E}_{t}$ is white noise. The model is written as:

$$
Y_{t}=Y_{t 1}+\sum_{i=1}^{p} a_{i} Y_{t i}+{ }_{t}
$$

Meanwhile, the PP test is indicated by using the equation as written below:

$$
Y_{t}=a_{0}+a_{1} Y_{t 1}+{ }_{t}
$$

Table 1 presents the unit root tests for the Augmented Dickey-Fuller and Phillips-Perron tests. 


\section{GENERAL MANAGEMENT}

\begin{tabular}{|c|c|c|c|c|}
\hline \multirow{3}{*}{ Leve } & \multicolumn{2}{|l|}{ ADF } & \multicolumn{2}{|c|}{ Phillip-Perron } \\
\hline & & & & \\
\hline & Intercept & $\begin{array}{l}\text { Intercept and } \\
\text { trend }\end{array}$ & Intercept & $\begin{array}{l}\text { Intercept and } \\
\text { trend }\end{array}$ \\
\hline $\mathrm{IF}$ & $-3.2451(9)^{\star * *}$ & $-3.8119(9)^{\star \star \star}$ & $-3.3443^{* *}$ & $-3.2442^{\star \star}$ \\
\hline TB & $-3.4551(9)$ & $-3.664(9)$ & -3.2231 & -3.2117 \\
\hline IR & $-3.2231(9)$ & $-3.7033(9)$ & -2.7995 & -2.6533 \\
\hline ITB & $-1.7661(9)$ & $-1.9455(9)$ & -2.4556 & -2.5112 \\
\hline IMR & $-1.9787(9)$ & $-1.8776(9)$ & -1.6010 & -1.7337 \\
\hline \multicolumn{5}{|c|}{ First Different } \\
\hline IF & $-6.5442(9)^{* \star *}$ & $-6.3395(9)^{\star \star *}$ & $-4.9886^{* \star *}$ & $-4.9292^{* * *}$ \\
\hline TB & $-9.7617(9)^{* * *}$ & $-9.4002(9)^{\star \star \star}$ & $-10.321^{* * *}$ & $-10.475^{\star * *}$ \\
\hline $\mathrm{IR}$ & $-6.6337(9)^{* * *}$ & $-5.7767(9)^{\star \star *}$ & $-5.0233^{* * *}$ & $-5.6642^{* * *}$ \\
\hline ITB & $-8.2344(9)^{* \star *}$ & $-8.1002(9)^{\star \star \star *}$ & $-8.3188^{\star * *}$ & $-8.2562^{* \star *}$ \\
\hline IMR & $-6.2143(9)^{* * *}$ & $-6.3110(9)^{\star \star \star}$ & $-6.2118^{* * \star}$ & $-6.2245^{\star \star *}$ \\
\hline
\end{tabular}

Table 1: Augmented Dickey-Fuller and Phillip-Perron unit root test results

Table 1 reveals all the variables are stationary at an order of $I(0)$ and $I(1)$ and this makes it possible to proceed with the ARDL bounds test. The stationarity of each variable is important to ensure that none of the variables are integrated in the order of I(2), which leads to an invalid result (El-Seoud, 2014).

\subsection{The ARDL Long-run Cointegration Approach}

The study next proceeds by examining the long-run relationship between interest rate and inflation by undertaking the ARDL bounds test (Pesaran and Shin, 1996, 1995). Below is the general model to discuss this relationship in the Malaysian money market:

$$
\begin{aligned}
& \Delta T B_{t}=c+\beta_{1} T B_{t-1}+\beta_{2} I F_{t-1}+\sum_{i=1}^{p} \alpha_{1 i} \Delta T B_{t-i}+\sum_{i=0}^{q} \alpha_{2 i} \Delta I F_{t-i}+\varepsilon_{t}(5) \\
& \Delta I R t=c+\beta_{1} I R+\beta_{2} I F_{t-1}+\sum_{i=1}^{p} \alpha_{1 i} \Delta I R_{t-i}+\sum_{i=0}^{q} \alpha_{2 i} \Delta I F_{t-i}+\varepsilon_{t} \\
& \Delta I T B_{t}=c+\beta_{1} I T B_{t-1}+\beta_{2} I F_{t-1}+\sum_{i=1}^{p} \alpha_{1 i} \Delta I T B_{t-i}+\sum_{i=0}^{q} \alpha_{2 i} \Delta I F_{t-i}+ \\
& \varepsilon_{t} \\
& \Delta I M R=c+\beta_{1} I M R+\beta_{2} I F_{t-1}+\sum_{i=1}^{p} \alpha_{1 i} \Delta I M R_{t-i}+\sum_{i=0}^{q} \alpha_{2 i} \Delta I F_{t-i}+\varepsilon_{t}
\end{aligned}
$$

In certain conditions, both criteria select the similar order of lag number for the conditional ECM in equation (2). The results are shown in Table 2 below.

\begin{tabular}{|l|l|l|l|l|}
\hline ARDL & \multicolumn{2}{l|}{$\begin{array}{l}\text { Step 1 } \\
\text { ARDL Bounds Test }\end{array}$} & \multicolumn{2}{l|}{$\begin{array}{l}\text { Step 2 } \\
\text { ARDL Level Relationships }\end{array}$} \\
\hline Interest rates & F-statistic & SBC (p,q) & ECMt-1 & p-value \\
\hline TB & $5.374^{*}$ & $(12,6)$ & 0.008 & 0.292 \\
\hline IR & $6.866^{* *}$ & $(12,12)$ & -0.032 & 1.618 \\
\hline ITBt & $7.234^{* *}$ & $(12,4)$ & -0.062 & 0.072 \\
\hline IMRt & $8.812^{* * *}$ & $(12,12)$ & -0.031 & 0.036 \\
\hline
\end{tabular}

Notes: *,**, and *** denote significance at the $10 \%, 5 \%$ and $1 \%$ levels, respectively

Table 2: Estimated Results for the Existence of a Long-run Cointegration Relationship

\begin{tabular}{|l|l|l|}
\hline Critical Value & Lower Bound & Upper Bound \\
\hline $1 \%$ significance level & 6.84 & 7.84 \\
\hline $5 \%$ significance level & 4.90 & 5.73 \\
\hline $10 \%$ significance level & 4.04 & 4.78 \\
\hline Null Hypothesis: No Cointegration & \multicolumn{2}{|l}{} \\
\hline
\end{tabular}

Notes: The Critical Value Developed by Pesaran et al. (2001) Under Case III: Unrestricted Intercepts; No Trends Table 3: Critical Values for ARDL Bounds Test

By referring to the critical value in Table 3, F-statistics for all variables in Table 2 ARDL bounds test have fallen above the upper bound. In the conventional money market, the computed F-statistics for TB are more than the upper bound 
critical value at $10 \%$. Meanwhile for IR, the computed Fstatistics are also more than the upper bound critical value at $5 \%$ and this supports the alternative hypothesis for the existence of a long-run cointegration relationship between the interest rate (TB and IR) and inflation in the conventional money market. For the Islamic money market, the result from the ARDL bounds test in Table 2 reveal the computed $F$ statistics for ITB are larger than the upper bound critical value at $10 \%$ as well as F-statistics for IMR is larger than the upper bound critical value at $1 \%$. This infers the cointegration between interest rates (ITB and IMR) and inflation rate in the Islamic money market.After validating the long-term cointegration in the ARDL bounds test, the ARDL level relationships are found by estimating Error Correction Model (ECM) to confirm the existence of Fisher Effect theory. Following Pesaran et al. (2001), the long-run cointegration in the ARDL bounds test does not specify perfect cointegration. These authors propose a negative value and significant error correction terms (ECMt-1) which indicate the long-term cointegration is stable and so the Fisher relationship is validated. In Table 2, the results present the coefficient of ECMt-1 for all the variables. The ECMt-1 for TB and IR is equal to 0.008 and -0.032 and both are not significant while the ECMt-1 in IR thus confirms no existence of a Fisher relationship. The result means that $T B$ and $I R$ are not fully adjusted by the movement in inflation (Al-Khazali, 2004). This finding is consistent with those of Alsmadi and Almsafir (2013) since they failed to support the Fisher relationship in the conventional money market. Hence, the results suggest the Fisher relationship does not exist in the conventional money market.

In contrast to ITB and IMR, the ECMt-1 value is equal to 0.062 and -0.031 and significant and thus infers the existence of Fisher Effect theory in the Islamic money market. Fisher Effect theory is supported in this market mainly due to the demands of Shariah principles in facilitating proper investment and a good investment alternative. The Islamic market has certain ethical filters and these practically forbid investment activities in areas of moral uncertainty (gharar), gambling (maisir) and interest (riba). So the Islamic money market can accurately predict inflation in the future where the existence of Fisher Effect theory has been confirmed. Additionally, the research by $\mathrm{Ho}$ et al. (2013) explains the operation of the Islamic market is to filter activities which are very different from the conventional market and must be ethically acceptable. This result agrees with the findings of Mahmood Ali et al. (2015) and Al- Sharkas and Al-Zoubi (2013) who support the Fisher Effect in Islamic countries. It suggests that the Malaysian Islamic money market does accurately predict future inflation.

\subsection{The Coefficient of Fisher Effect Theory}

Since the ITB and IMR confirm the existence of a Fisher relationship, the study next proceeds with one-for-one changes between the interest rate and inflation in its strictest form as suggested by Fisher Effect theory (Ahmad, 2010). For this purpose, the null hypothesis of $\mathrm{HO}: \beta=1$ was examined to determine the strong form of the Fisher relationship. From Table 4, the p-value for both ITBt and IMRt are significant at 1 percent which means the strong form Fisher Effect is rejected. This indicates the alternative hypothesis is supported which means the Fisher relationship in the Malaysian Islamic money market has a weak form. This situation demonstrates that the Islamic money market moves efficiently between interest rate and inflation but the effect is very minimal. This finding is consistent with llahi et al. (2015) since they found a weak correlation between interest rate and inflation when discussing the Karachi Stock Exchange 100 index in Pakistan. They suggest there is a weak relationship between interest rate and inflation and it has less impact on the stock exchange market. Consequently, it provides foreign investors with less risk.

\begin{tabular}{|l|l|}
\hline Variables & Chi-Square \\
\hline ITB & $17235.1(0.000)$ \\
\hline IMR & $17622.8(0.000)$ \\
\hline
\end{tabular}

Notes: p-value in the parentheses (...) shows the probability of Chi-square.

Table 4: The Coefficient of Fisher Relationship

\subsection{Diagnostic Test}

To ensure the models are dynamically stable and there is no serial correlation problem, all model regressions have been checked for the diagnostic test, namely Cumulative Sum Recursive Residuals (CUSUM) and Lagrange Multiplier (LM) tests. The LM test estimates no serial correlation problem exists ( $p$-value is greater than 0.05) and CUSUM tests indicate the stability within the bounds and significant at the $5 \%$ level. Furthermore, the results suggest all models in ARDL cointegration are dynamically stable so the findings are validated.

\section{Conclusion And Recommendation}

This research aims to find the existence the Fisher relationship by estimating the relationship between interest rate and inflation in Malaysia's money market, specifically in the conventional and Islamic markets. To fulfil the objectives, this study employs the ARDL cointegration proposed by Pesaran et al. (2001) in the first stage of analysis. The findings disclose the significant long-run cointegration among interest rates and inflation Islamic money market so the Fisher relationship is supported. However, the conventional money market records no evidence supporting the validity of Fisher Effect theory. Meanwhile, in the second stage of analysis the Fisher relationship in the Islamic money market is proven to exist in a weak form. This finding rejects the null hypothesis of one-to-one movement between the interest rate and inflation rate, and this suggests a strict form of the Fisher Effect.The main issue which needs to be highlighted from the results is that although the Malaysian Islamic money market does not confirm the existence of a Fisher relationship, the relationship still exists in a weak form. This contends that the Malaysian Islamic money market can accurately predict future inflation in Malaysia but the impact is minor. The existence of Fisher Effect in the Islamic money market is mainly due to the conservative nature of Shariah principles that offer a best investment alternative for investors. For this reason, the movement between interest rate and inflation rate in the Islamic money market behaves in a different way to the conventional money market. It is very interesting to note where there is a widespread attraction to Shariah-compliant investments due to their more equitable and profit-sharing 
characteristics. Furthermore, the Islamic money market in Malaysia has been inject a large amount of funds as a result of government support to promote the Islamic finance industry and wanting Malaysia to be a major centre for international Islamic finance. The outputs from this research will provide good ideas for policymakers and government officials to implement. They can utilise the direction of the Fisher relationship as a guideline to create an effective monetary policy for sustainable long-term economic growth. Moreover, the findings from this study will advantage depositors and investors when the interest rate is able to predict inflation in the future (Ho et al., 2013). For instance, in the event of economic recession, depositors and investors may adjust their investment portfolios by choosing assets that hedge against inflation to minimise any risk. This research has several limitations. Firstly, its scope only concentrates on the existence of a Fisher relationship in the Malaysian money market. Future researchers could conduct further investigations in the equity and bond markets since they also employ Islamic market instruments. Secondly, this research focuses on the validity of the Fisher relationship in Malaysia. However, there are only a few other countries that practice a dual banking system, for example Indonesia. Therefore, it is advised to determine the validity of a Fisher relationship in other countries that have a dual banking system. Last but not least, in terms of estimation method, this research employs ARDL cointegration time-series analysis from 2011 until 2018. Recently, several estimations have been introduced to provide robust results. For instance, future research may undertake the advanced method of ARDL, namely, non-linear ARDL which makes it possible to model the non-linear impact of independent variables on the dependent variables.

\section{Acknowledgements}

We would like to thank the editors and the anonymous referees of the journal for their constructive comments and suggestions, which have significantly helped to improve the paper. Furthermore, special thanks to: 1) Fundamental Research Grant Scheme (FRGS) Project Code: 600IRMI/FRGS 5/3 (141/2019) sponsored by Malaysian Ministry of Higher Education; 2) Universiti Teknologi MARA, Malaysia; and 3) Sustainable Research Collaboration Grant Project Code: $600-R M C / S R C / 5 / 3$ (002/2020) sponsored by Universiti Malaysia Pahang as organisations that funded our research. 4) Thanks to Universiti Teknikal Malaysia Melaka for research support. The usual caveats apply.

\section{References}

[1] Abd Rahman, N. H., Md Sahiq, A. N., Ismail, S., Bakri, M. H., \& Husin, A. (2016). Antecedents of a Successful Business Venture for Young Entrepreneurs. Advanced Science Letters, 22(12), 4485-4488. doi:10.1166/asl.2016.8195

[2] Ahmad, S. (2010). The long-run Fisher effect in developing economies. Studies in Economics and Finance, 27(4), 268-275. doi:10.1108/10867371011085129

[3] Alimi, S. R., \& Ofonyelu, C. C. (2013). Toda-Yamamoto Causality Test Between Money Market Interest Rate and Expected Inflation: the Fisher Hypothesis Revisited. European Scientific Journal, 9(7). https://doi.org/10.19044/esj.2013.v9n7p\%p

[4] Al-Khazali, O. M. (2004). The generalized Fisher hypothesis in the Asian markets. Journal of Economic Studies, 31(2), 144-157. doi:10.1108/01443580410527123

[5] Al-Sharkas, A. A., \& Al-Zoubi, M. (2013). Stock Prices and Inflation: Evidence from Jordan, Saudi Arabia, Kuwait, and Morocco. Journal of Business Research, 12(1), 23-39.
[6] Almsafir, M. K., \& Alsmadi, A. A. (2014). Murabahah Versus Interest Rate, the Equilibrium Relationship with Macroeconomic Variables in Jordanian Economy: An ARDL Approach. Procedia Social and Behavioral Sciences, 129, 349-357. doi:10.1016/j.sbspro.2014.03.687.

[7] Anari, A., \& Kolari, J. (2016). Dynamics of interest and inflation rates. Journal of Empirical Finance, 39, 129-144. doi:10.1016/j.jempfin.2016.08.008

[8] Asari, F. F. A. H., Baharuddin, N. S., Jusoh, N., Mohamad, Z., \& Jusoff, N. S. K. (2011). A Vector Error Correction Model ( VECM ) Approach in Explaining the Relationship Between Interest Rate and Inflation Towards Exchange Rate Volatility in Malaysia. World Applied Sciences Journal, 12, 49-56.

[9] Atkins, F. J. (1989). Co-integration, error correction and the Fisher effect. Applied Economics, 21(12), 1611-1620. doi: $10.1080 / 758531695$

[10] Auclert, A. (2019). Monetary Policy and the Redistribution Channel. American Economic Review, 109(6), 2333-2367. doi:10.1257/aer.20160137

[11] Awomuse, B.O. \& Alimi, R.S (2012). The relationship between Nominal Interest Rates and Inflation: New Evidence and Implications for Nigeria. Journal of Economics and Sustainable Development, 3(9).

[12] Crowder, W. J., \& Hoffman, D. L. (1996). The Long-Run Relationship between Nominal Interest Rates and Inflation: The Fisher Equation Revisited. Journal of Money, Credit and Banking, 28(1), 102. doi:10.2307/2077969

[13] DARBY, M. R. (1975). THE FINANCIAL AND TAX EFFECTS OF MONETARY POLICY ON INTEREST RATES. Economic Inquiry, 13(2), 266-276. doi:10.1111/j.1465-7295.1975.tb00993.x

[14] Dickey, D. A., \& Fuller, W. A. (1979). Distribution of the Estimators for Autoregressive Time Series with a Unit Root. Journal of the American Statistical Association, 74(366a), 427431. doi:10.1080/01621459.1979.10482531

[15] Dutt, S. D., \& Ghosh, D. (1995). The Fisher hypothesis: examining the Canadian experience. Applied Economics, 27(11), 1025-1030. doi:10.1080/00036849500000084

[16] El-Seoud, S. A. (2014). The effect of interest rate, inflation rate and GDP on national savings rate. Global Journal of Commerce \& Management Perspective, 3(3), 1-7.

[17] Engle, R. F., \& Granger, C. W. J. (1987). Co-Integration and Error Correction: Representation, Estimation, and Testing. Econometrica, 55(2), 251. doi:10.2307/1913236

[18] EVANS, M. D. D., \& LEWIS, K. K. (1995). Do Expected Shifts in Inflation Affect Estimates of the Long-Run Fisher Relation? The Journal of Finance, 50(1), 225-253. doi:10.1111/j.15406261.1995.tb05172.x

[19] Evans, M. D. D. (1998). Real Rates, Expected Inflation, and Inflation Risk Premia. The Journal of Finance, 53(1), 187-218. doi:10.1111/0022-1082.75591.

[20] Fah, Cheng Fan, \& Annuar, N. (2012). A Cointegration Tests on Malaysian Government Securities (MGS) Spreads and Inflation 1. Terengganu International Finance and Economics Journal, 2(1), 15-27.

[21] Fahmy, Y. A. ., \& Kandil, M. (2003). The Fisher effect: new evidence and implications. International Review of Economics \& Finance, 12(4), 451-465. doi:10.1016/s1059-0560(02)00146-6.

[22] Fama, E. F. (1975). Short-terms Interest Rates as a Predictors of Inflation. Journal of Financial Economics, 65, 269-282.

[23] Fatima, N., \& Sahibzada, S. A. (2012). Empirical Evidence of Fisher Effect in Pakistan. World Applied Sciences Journal, 18(6), 770-773. doi: 10.5829/idosi.wasj.2012.18.06.1118

[24] C., L. R., \& Fisher, I. (1930). The Theory of Interest. Journal of the Royal Statistical Society, 93(3), 450. doi:10.2307/2342072.

[25] Geetha, C., Chong, V., Mohidin, R., \& Vivin Vincent Chandran. (2011). The Relationship Between Inflation and Stock Market: Evidence from Malaysia, United States and China. International Journal of Economics and Management Sciences, 1(2), 1-16.

[26] Gul, E., \& Acikalin, S. (2008). An examination of the Fisher Hypothesis: the case of Turkey. Applied Economics, 40(24), 3227-3231. doi:10.1080/00036840600994112

[27] Gul, E., \& Ekinci, A. (2006). The Causal Relationship Between Nominal Interest Rates and Inflation: The Case of Turkey. Scientific Journal of Administrative Development, 4, 54-69.

[28] Hawati, J., Ruzita, R., Hasimi, Y., \& Izani, I. (2010). Stock Returns and Inflation with Supply and Demand Shocks: Evidence from Malaysia. Jurnal Ekonomi Malaysia, 44, 3-10. 
[29] Ho, C. S. F., Abd Rahman, N. A., Yusuf, N. H. M., \& Zamzamin, Z. (2014). Performance of global Islamic versus conventional share indices: International evidence. Pacific-Basin Finance Journal, 28, 110-121. doi:10.1016/j.pacfin.2013.09.002

[30] Ilahi, I., Ali, M., \& Jamil, R. A. (2015). Impact of Macroeconomic Variables on Stock Market Returns: A Case of Karachi Stock Exchange. SSRN Electronic Journal. doi:10.2139/ssrn.2583401

[31] Johansen, S., \& Juselius, K. (2009). MAXIMUM LIKELIHOOD ESTIMATION AND INFERENCE ON COINTEGRATION - WITH APPLICATIONS TO THE DEMAND FOR MONEY. Oxford Bulletin of Economics and Statistics, 52(2), 169-210. doi:10.1111/j.1468-0084.1990.mp52002003.x

[32] Junttila, J. (2001). Testing an augmented fisher hypothesis for a small open economy: The case of Finland. Journal of Macroeconomics, 23(4), 577-599. doi:10.1016/s01640704(01)00179-3

[33] Lee, K. F. (2007). An Empirical Study of the Fisher Effect and the Dynamic Relation between Nominal Interest Rates and Inflation in Singapore, MPRA Paper No. 12383.

[34] Safdari Mahdi. (2011). The long run relationship between interest rates and inflation in Iran: Revisiting Fisher's hypothesis. Journal of Economics and International Finance, 3(14). doi:10.5897/jeif11.075

[35] Mahmood Ali, T., Tariq Mahmood, M., \& Bashir, T. (2015). Impact of Interest Rate, Inflation and Money Supply on Exchange Rate Volatility in Pakistan. World Applied Sciences Journal, 33(4), 620-630. https://doi.org/10.5829/idosi.wasj.2015.33.04.82

[36] Mishkin, Frederic S. The Economics of Money, Banking, and Financial Markets. 16th ed., Pearson, 2016.

[37] Md Nassir, A., Shamser, M., \& Zainal, M. A. (1987). An Empirical Study of the Treasury Bill Market in Malaysia: Using Treasury Bill as a Predictor of Inflation. Pertanika Universiti Putra Malaysia, 16(3), 349-355.

[38] NOOR, N. H. H. M., BAKRI, M. H., YUSOF, W. Y. R. W., NOOR N. R. A. M., \& ZAINAL, N. (2020). The Impact of the Bank Regulation and Supervision on the Efficiency of Islamic Banks. The Journal of Asian Finance, Economics and Business, 7(11), 747-757. doi:10.13106/jafeb.2020.vol7.no11.747

[39] NOOR, N. H. H. M., BAKRI, M. H., YUSOF, W. Y. R. W., NOOR, N. R. A. M., \& ABDULLAH, H. (2020). The Determinants of Bank Regulations and Supervision on the Efficiency of Islamic Banks in MENA Regions. The Journal of Asian Finance, Economics and Business, $7(12)$ doi:10.13106/jafeb.2020.vol7.no12.245

[40] Nusair, S. A. (2009). Non-linear Co-integration between Nominal Interest Rates and Inflation: An Examination of the Fisher
Hypothesis for Asian Countries. Global Economic Review, 38(2), 143-159. doi:10.1080/12265080902891446

[41] Obi, B., A. Nurudeen \& Wafure, O.G. (2009). An Empirical investigation of the Fisher Effect in Nigeria: Co-Integration and Error Correction Approach. International Review of Business Research Papers, 5(5): 96-109.

[42] Ouattara, B. (2004). Modelling the Long Run Determinants of Private Investment in Senegal. Credit Research Paper (04), 121.

[43] Panopoulou, E. (2005). A Resolution of the Fisher Effect Puzzle: A Comparison of Estimators. Retrieved from http://economics.nuim.ie/research/workingpapers/documents/N1 500205.pdf

[44] Pesaran, M. H., Shin, Y., \& Smith, R. J. (2001). Bounds testing approaches to the analysis of level relationships. Journal of Applied Econometrics, 16(3), 289-326. doi:10.1002/jae.616

[45] Pesaran, M. H., Shin, Y., \& Smith, R. P. (1999). Pooled Mean Group Estimation of Dynamic Heterogeneous Panels. Journal of the American Statistical Association, 94(446), 621-634. doi:10.1080/01621459.1999.10474156

[46] PHILLIPS, P. C. B., \& PERRON, P. (1988). Testing for a unit root in time series regression. Biometrika, 75(2), 335-346. doi:10.1093/biomet/75.2.335

[47] Seng, N. D., bin Bakri, M. H., Al Shami, S. A., Hamid, B. A., \& Zainal, N. (2020). Determinants contributing to the primary market spread of securitization in Malaysia. International Journal of Innovatio n, Creativity and Change, 11(12), 137-148.

[48] Vianneca W. Jubilee, R., Kamarudin, F., Iqbal Hussain, H., Razman Abdul Latiff, A., \& Zainal, N. (2020). Analysis of Total Factor Productivity Changes in Islamic and Conventional Banks: Empirical Evidence from Three Regions. International Journal of Management and Sustainability, 9(3), 161-180. doi:10.18488/journal.11.2020.93.161.180

[49] Weidmann, J. (1997). New Hope for the Fisher Effect? A Reexamination Using Threshold Co-integration, University of Bonn Discussion Paper B-385.

[50] Zainal, N., Nassir, A. M., Kamarudin, F., Hook, L. S., Sufian, F., \& Hussain, H. I. (2019). Social role of microfinance institutions in poverty eradication: Evidence from ASEAN-5 countries. International Journal of Innovation, Creativity and Change, 5(2), 1551-1576.

[51] Zainal, N., Nassir, A. M., \& Yahya, M. H. (2014). Fisher Effect: Evidence From Money Market in Malaysia. Journal of Social Science Studies, 1(2), 112. doi:10.5296/jsss.v1i2.4915 